$\xi=-1$

\title{
Ukraine Unified Transport System Potential and Its Development Management Effectiveness Integral Assessment
}

\author{
Komelina Olha*1 ${ }^{1}$, Dubishchev Viktor ${ }^{1}$, Lysenko Mykola ${ }^{1}$, Panasenko Nataliia ${ }^{1}$ \\ ${ }^{1}$ Poltava National Technical Yuri Kondratyuk University \\ *Corresponding author E-mail: komelinaolha@gmail.com
}

\begin{abstract}
Transport system is an important constituent of country's economy. This system development is a significant factor ensuring population standard of living. Research in the field of unified transport system of Ukraine development estimates reveals its condition as not sufficient to meet modern requirements.

Among the problems which are to be first of all solved to improve transport system of Ukraine operation estimates, an important place belongs to the issues of industry management information and analytical provision: lack of data collecting and processing effective system, methodology for objective condition assessment and prospective of the industry development, systematic approach to development coordination and long-term panning of all modes of transport operation, criteria and indices for quality estimation in providing transportation services. Solving these problems is impossible without significant improving the country's unified transport system management. Transport infrastructure in Ukraine requires considerable systemic changes, oriented to logistics which will provide integration effect, reduce costs and improve service quality.

Methodology for the national economy transport system development integral estimation was developed based on the modern information base including approach to determining peculiarities of forming transport system of Ukraine potential and its development management effectiveness under global challenges. The developed methodical approach can be efficiently used for analyses, control, accounting, planning, forecasting and regulating the industry activity at the national and regional levels and the level of separate country's transport subsystems. Suggested approach can be used for evaluating efficiency of transport system development innovative and investment projects, and is the basis for defining market transformation vectors considering its socially optimal development level as well as regarding innovative and investment projects financing.
\end{abstract}

Keywords: effectiveness of management; integral assessment; potential; transport system.

\section{Introduction}

The country's transport system development is one of the main factors providing the state economic interests ensuring and contributing to raising population standard of living. Tnified transport system of Ukraine which has a complex structure and includes motor, railway, urban, marine, air, river and pipeline modes of transport, was created in the twentieth century and integrated into the former Soviet Union transport system. In general it meets the needs of national economy and population, but indicators of its operation quality and efficiency of do not meet modern requirements. Changing approaches to the essence of transport services and system of requirements for expediency, completeness and quality of its provision in order to meet the population and economy needs in transportation by all modes of transport, new challenges for the national economy development, implementation tasks of the Agreement on Ukraine and the EU integration, reorientation of domestic and foreign traffic flows to new markets require exploration of transport system development potential, identification of its new strategic orientations and formation of a wellbalanced state sector of transport infrastructure development. The main problems of transport industry include capital consumption, insufficient amount of investments necessary to upgrade and provide innovative development of the industry material and tech- nical base, financing limited budget, need for infrastructure reequipment and modernization, and highway network development. To solve these problems it is necessary to increase management efficiency of a unified transport system, which requires improvement in industry information and analytical support. An integral part of such support is integrated assessment methodology, which enables conducting analysis, control, accounting, planning, forecasting and regulation of the industry.

\section{Results and Discussion}

Theoretical and practical aspects of transport system assessment and certain modes of transport are investigated in many scientific publications. In [1] comprehensive assessment for various integrated transport systems and integrated transport planning assessment index system are defined. A. Čech and Ye. Levchuk [2] evaluated development of transport in a number of countries, using methods that take into account interaction between different sectors of transport system. A new approach to evaluating transport system efficiency is suggested in [3]. The authors developed a model that includes 6 output and 9 input variables and contains financial indicators, transport accessibility indicators, and others. While studying formation and functioning of regional transport and logistics systems, scientists developed a method for 
integrated assessment and algorithm for transport system comprehensive analysis [4].

New global challenges of economic development caused introduction of new aspects in transport system research. N. O. Iksarova [5] draws attention to the need of transport infrastructure study as an important component of Ukraine's economic security. O. Zakharova [6] investigated peculiarities of world transport system potential development and influence of global factors on world transport development. Development of transport system in Ukraine is analysed in analytical report [7], the main problems of transport industry development and Ukraine's transport system integration into European and world transport networks are identified. In [8], it is suggested to extend assessment of urban transport system obtained on the basis of economic (quantitative) criteria with integrated evaluation methods based on multicriteria and socioeconomic analysis that consider both quantitative and qualitative criteria.

Further development of transport services market and understanding of transport system concept as a means of communication, technical facilities of transport and transportation services, which combine all modes of transport and components of transportation process in their interaction and ensure successful functioning of national complex as a whole, caused a series of publications concerning new approaches to their evaluation, generalization of which enables determining directions for their development 1) introduction of new criteria for assessing transportation service (passenger loading speed (or cargo loading/ loading off), service reliability, average dwell time and block speed) [9]; 2) evaluation of spatial development as a result of the territory transport and logistics system implementation level (in particular, metropolitan function of a large city) [10]; research of integrated influence on territories development by means of constructing system-based dynamical models for investigation complex connections between transport system separate components; 4) integrated assessment of transport system development and level of attracting different modes of transport to the economy (country, region, city, etc.), as well as interconnection of Ukraine's motor transport system development and country regions industrial infrastructure in their interaction, and ensure successful functioning of country national complex as a whole [12-14].

In the context of transportation systems types, the following publications are worth attention: analytical modeling, conceptual planning and multicriteria assessment of transportation systems particular types operated by various types of transport, such as motor, railway, marine, air [15]; definition and analysis of integral indices of railway transport sustainable development current state in general and in terms of its separate components [16]; comprehensive assessment of passenger railway transport quality, considering logistics functions, which include appropriate assessments scale [17]; creation a model for multicriteria analysis of motor transport development which includes indicators of ecology, road safety, environmental mobility and quality of living [18].

Thus, there are a lot of scientific papers dedicated to comprehensive assessment of towns and regions transport systems, as well as to certain modes of transport. At the same time, the problem of integrated assessment of the country's entire transportation system is not given enough attention.

The purpose of the article is to develop methodology for integrated assessment of the country's transport system development and to determine on its basis integral estimation of Ukraine transport system and its subsystems.

Unified transport system of Ukraine includes public transport (railway, marine, river, motor, aircraft, urban electric transport, including underground), industrial railway, departmental; pipelines and public transport routes [19].

Transport complex contributes to the development of all branches of the country's economy, provides economic relations between different regions as well as foreign economic relations. Transport system of Ukraine includes transport infrastructure, transport enterprises, vehicles and management system of this branch. Ukraine transport network in 2016 included 21 thousand kilometers of railways (including 10 thousand $\mathrm{km}$ of electrified ones), 163.0 thousand $\mathrm{km}$ of highways (including 150.5 thousand $\mathrm{km}$ of hardsurface roads), 1.6 thousand $\mathrm{km}$ of river navigable roads, 3.3 thousand $\mathrm{km}$ of trolleybus lines (in a one-way calculation), 1.6 thousand $\mathrm{km}$ of tram tracks (in one-way calculation), 113.4 thousand kilometers of underground tracks (in two-track calculation). There are 13 seaports operating in Ukraine, total capacity of which is equal to about 230 million tons a year.

Conducted analysis of Ukraine transport system showed that there is a negative dynamics in a number of important indicators. Thus, in 2016, as compared to 2004, goods railway transportation decreased by $25.76 \%$, marine - by $66.7 \%$, river - by $66.7 \%$, gas pipelines transportation - by $45.7 \%$, oil pipelines transportation by $72.7 \%$. Railway transport cargo turnover in 2016 , as compared to 2004 , decreased by $19.83 \%$, marine - by $73.12 \%$, and river - by $73.21 \%$. Passengers railway transportation in 2016 compared to 2004 decreased by $13.94 \%$, river - by $50.0 \%$, motor - by $47.47 \%$. Main indicators of urban transport operation deteriorated: passengers trolleybus transportation decreased in 2016, as compared to 2004 , by $47.54 \%$, city buses transportation - by $43.62 \%$, trams by $37.59 \%$, underground - by $17.69 \%$. At the same time, there is a positive trend in a number of indicators dynamics. Thus, goods motor transportation increased in 2016, as compared to 2004, by $5.74 \%$, passengers air transportation - by $66.7 \%$, length of the first category highways - by $20.25 \%$.

To improve transport system operation indices in Ukraine, a number of problems have to be solved, among which are the following: lack of effective system for data collection and data processing in transport sector, objective assessment of its condition and development prospects; lack of a systematic approach to development coordinating and long-term planning of all modes of transport operation; lack of effective control systems for managerial decisions making effectiveness; lack of a system for establishing criteria and indicators for assessing transport services quality.

Complexity in solving the above-mentioned problems and significant role of information technology for making managerial decisions determines the need for development and application of a methodology for the integrated assessment of the country's transport system.

Algorithm of the authors' methodical approach to the country's transport system integral evaluation includes several stages.

$\mathbf{1}^{\text {st }}$ stage. Selection of indicators and defining criteria for assessing the country's transport system development.

Since control of a large number of transport system's operation various indicators is a complex task, it is preferable to systematize these data and determine complex assessments of the whole system and its subsystems. Such factorization of the set of indicators enables significant reduction in their number without losing informativity, which will facilitate making managerial decisions, control over their implementation, planning and forecasting the given industry development.

We suggest dividing a number of indicators for assessing the country's transport system performance into subsets according to mode of transport: motor, railway, river, city, marine, air and pipelines. In each subset indicators reflecting the results of respective type of transport activity are to be allocated, as well as indicators reflecting resource potential of this type of transport.

The research was conducted for the period from 2004 to 2016 . The chosen period is interesting in terms of changing the content of Ukraine's state economic policy as a whole and its mechanisms for ensuring transport industry development in particular.

The indicators selected give an opportunity to evaluate national economy's transport system development both quantitatively (resource potential) and qualitatively (resource potential management effectiveness). Unfortunately, limitation of aggregate official statistics on the transport system development does not allow obtaining more detailed information.

The list of indicators is given in Table 1 . 
Table 1: Indicators of the transport system of Ukraine

\begin{tabular}{|c|c|}
\hline Symbols & Symbols Explanation \\
\hline$x_{111}$ & Goods motor transportation (million tons) \\
\hline$x_{112}$ & $\begin{array}{l}\text { Motor transport cargo turnover (billions of tonne- } \\
\text { kilometres) }\end{array}$ \\
\hline$x_{113}$ & Passengers motor transportation (mln.) \\
\hline$x_{114}$ & Passenger motor transport turnover (billions of passengers) \\
\hline$x_{121}$ & Length of motorways $(\mathrm{km})$ \\
\hline$x_{122}$ & Length of first category motorways $(\mathrm{km})$ \\
\hline$x_{123}$ & Length of second category motorways (km) \\
\hline$x_{124}$ & Length of third category motorways (km) \\
\hline$x_{125}$ & Length of fourth category motorways (km) \\
\hline$x_{126}$ & Length of fifth category motorways (km) \\
\hline$x_{127}$ & Number of covered bus stops (units) \\
\hline$x_{128}$ & Number of motorways stagings (units) \\
\hline$x_{129}$ & Number of highways public conveniences (units) \\
\hline$x_{12 \overline{10}}$ & $\begin{array}{l}\text { Motorways roadside wells and drinking water sources in } \\
\text { (units) }\end{array}$ \\
\hline$x_{12 \overline{11}}$ & $\begin{array}{l}\text { Length of snow-retaining plantations along motorways } \\
(\mathrm{km})\end{array}$ \\
\hline$x_{12 \overline{12}}$ & Length of anti-erosion plantings along motorways (km) \\
\hline$x_{211}$ & Railway transport export and import balance of (mln USD) \\
\hline$x_{212}$ & Railway goods transportation (million tons) \\
\hline$x_{213}$ & $\begin{array}{l}\text { Railway transport cargo turnover (billions of tonne- } \\
\text { kilometres) }\end{array}$ \\
\hline$x_{214}$ & Passenger railway transportation $(\mathrm{mln})$ \\
\hline$x_{215}$ & Railway passenger traffic (billions of passengers) \\
\hline$x_{221}$ & Number of locomotives (units) \\
\hline$x_{222}$ & Number of freight wagons (ths) \\
\hline$x_{223}$ & Number of passenger compartment (ths) \\
\hline$x_{224}$ & Railways operating length (thousand km) \\
\hline$x_{311}$ & Passenger trolley buses transportation (mln.) \\
\hline$x_{312}$ & Passenger city buses transportation (mln.) \\
\hline$x_{313}$ & Passenger tram transportation (mln) \\
\hline$x_{314}$ & Passenger underground transportation (million) \\
\hline$x_{315}$ & Passenger trolleybus transport traffic (billions of bucks) \\
\hline$x_{316}$ & Passenger tram transport traffic (billions of bucks) \\
\hline$x_{317}$ & $\begin{array}{l}\text { Passenger subway transport turnover (billions of passen- } \\
\text { gers) }\end{array}$ \\
\hline$x_{321}$ & Number of trolleybus cars (units) \\
\hline$x_{322}$ & Number of tram cars (units) \\
\hline$x_{323}$ & Number of subway carriages (units) \\
\hline$x_{324}$ & Trolleybus lines operating length (thousand km) \\
\hline$x_{325}$ & Tram tracks operating length (thousand km) \\
\hline$x_{236}$ & Underground tracks operating length of $(\mathrm{km})$ \\
\hline$x_{411}$ & $\begin{array}{l}\text { Marine transport export and import balance (millions of US } \\
\text { dollars) }\end{array}$ \\
\hline$x_{412}$ & Marine goods carriage (million tons) \\
\hline$x_{413}$ & Marine transport cargo turnover (billion tonne-kilometres) \\
\hline$x_{414}$ & Marine passenger transportation (mln.) \\
\hline$x_{415}$ & Marine transport passenger traffic (billions of tkm) \\
\hline$x_{421}$ & Number of marine vessels (units) \\
\hline$x_{511}$ & $\begin{array}{l}\text { Air transport export and import surplus (millions of US } \\
\text { dollars) }\end{array}$ \\
\hline$x_{512}$ & Air goods transportation (million tons) \\
\hline$x_{513}$ & Air transport cargo turnover (billions of tkm) \\
\hline$x_{514}$ & Passenger air transportation (mln.) \\
\hline$x_{515}$ & Passenger air transport traffic (billions of passengers) \\
\hline$x_{521}$ & Number of planes and helicopters (units) \\
\hline$x_{611}$ & River transport goods transportation (million tons) \\
\hline$x_{612}$ & River transport cargo turnover (billion tonne-kilometres) \\
\hline$x_{613}$ & River transport passenger transportation by $(\mathrm{mln})$ \\
\hline$x_{614}$ & River transport passenger traffic (billions of bucks) \\
\hline
\end{tabular}

\begin{tabular}{|l|l|}
\hline$x_{621}$ & Number of river vessels (units) \\
\hline$x_{622}$ & River navigable roads operating length (thousand km) \\
\hline$x_{711}$ & $\begin{array}{l}\text { Pipeline transport export-import balance (millions of US } \\
\text { dollars) }\end{array}$ \\
\hline$x_{712}$ & Pipelines gas transportation (million tons) \\
\hline$x_{713}$ & Pipelines oil transportation (million tons) \\
\hline$x_{714}$ & Pipelines ammonia transportation (million tons) \\
\hline$x_{715}$ & $\begin{array}{l}\text { Pipeline transport cargo turnover (gas) (billion tonne- } \\
\text { kilometres) }\end{array}$ \\
\hline$x_{716}$ & $\begin{array}{l}\text { Pipeline transport cargo turnover (oil) (billion tonne- } \\
\text { kilometres) }\end{array}$ \\
\hline$x_{717}$ & $\begin{array}{l}\text { Pipeline transport (ammonia) cargo turnover of (billion } \\
\text { tonne-kilometres) }\end{array}$ \\
\hline
\end{tabular}

Let us denote the selected indicators by $x_{i j k}$, where index $\mathrm{i}$ corresponds to the ьщву of transport $(\mathrm{i}=1-\operatorname{road}, \mathrm{i}=2-$ railway, $\mathrm{i}=3$ - city, $\mathrm{i}=4$ - sea, $\mathrm{i}=5$ - air, $\mathrm{i}=6$ - river, $\mathrm{i}=7$ - pipeline ), index $\mathrm{j}$ indicates what this indicator displays $(\mathrm{j}=1$ - results of transport operation, $\mathrm{j}=2$ - level of this type of transport resources supply), index $\mathrm{k}$ is the ordinal indicator number in the corresponding subset. Let us denote indicator value $x_{i j k}$ by $x_{i j k t}$ per year $\mathrm{t}$, where $\mathrm{t}$ is serial number of the year in the period investigated. In order to obtain integral estimates, it is necessary to determine normalized indicators $y_{i j k}$, which values belong to the interval $[0 ; 1]$. Normalization is carried out through equality

$$
y_{i j k t}=\frac{x_{i j k t}}{\max \left(x_{i j k t}\right)} \text {. }
$$

Integral estimate of transport system for the period $\mathrm{t}$ is determined through equality

$$
W_{t}=\sum_{i=1}^{N} \alpha_{i}\left(\lambda_{i 1} \sum_{k=1}^{m_{i}} \gamma_{i 1 k} y_{i 1 k t}+\lambda_{i 2} \sum_{k=1}^{n_{i}} \gamma_{i 2 k} y_{i 2 k t}\right)
$$

where $\alpha_{\mathrm{i}}$ is weight factor of i-th type of transport, $\lambda_{\mathrm{i} 1}$ and $\lambda_{\mathrm{i} 2}$ respectively are weight ratios of performance indicators and maintenance indicators for $\mathrm{i}$-th type of transport, $\gamma_{\mathrm{ilk}}$ - weight factor of $\mathrm{k}$ th indicator in the set of performance indicators of i-th type of transport, $\gamma_{\mathrm{i} 2 \mathrm{k}}-$ weight factor of $\mathrm{k}$-th indicator in the set of supply indicators for the $\mathrm{i}$-th type of transport, mi and $n_{i}$ respectively the number of performance indicators and performance indicators for the i-th type of transport, $\mathrm{N}$ - number of types of transport.

$2^{\text {nd }}$ stage. Implementation of the country's transport system integrated assessment.

To determine integral estimation of transport system, it is necessary to calculate weight coefficients $\alpha_{\mathrm{i}}, \lambda_{\mathrm{i} 1}, \lambda_{\mathrm{i} 2}, \gamma_{\mathrm{i} 1 \mathrm{k}}$ and $\gamma_{\mathrm{i} 2 \mathrm{k}}$. Different methods are used for their calculation [20]. We suggest applying the method of a modified first main component, which does not include expert estimation, based on objective statistical indicators and reflects relationship between these indicators. To calculate weight coefficients $\gamma_{\text {ilk }}$ let us determine the covariance matrix of normalized indicators, the elements of which are the coefficients of covariance $\operatorname{cov}\left(y_{i 1 k^{\prime}}, y_{i 1 k^{\prime \prime}}\right)$, where $k^{\prime}, k^{\prime \prime}=\overline{1, m_{i}}$. Assume $V_{i 1}=\left\{v_{i 11}, v_{i 12}, \ldots, v_{i 1 m_{i}}\right\}$ to be an own vector of a given matrix corresponding to its maximum eigen value. Then we choose weight coefficients $\gamma_{\mathrm{ilk}}$ as proportional to the squares of vector component $\mathrm{V}_{\mathrm{i} 1}$. These coefficients enable determining integral estimate $W_{i 1 t}=\sum_{k=1}^{m_{i}} \gamma_{i 1 k} y_{i 1 k t}$ of performance indicators of the i-th mode of transport. Similarly, we determine weight coefficients $\gamma_{\mathrm{i} 2 \mathrm{k}}$ and integral estimation $W_{i 2 t}=\sum_{k=1}^{n_{i}} \gamma_{i 2 k} y_{i 2 k t}$ of supply indicators of the i-th mode of transport. Weights coefficients $\lambda_{\mathrm{i} 1}$ and $\lambda_{\mathrm{i} 2}$ are 
proportional to the squares of the eigen vector $V_{i}=\left\{v_{i 1}, v_{i 2}\right\}$, corresponding to the maximal eigen value of the covariance matrix of integral indicators $\mathrm{W}_{\mathrm{i} 1}$ and $\mathrm{W}_{\mathrm{i} 2}$. Thus we determine integral estimates

$W_{i t}=\lambda_{i 1} \sum_{k=1}^{m_{i}} \gamma_{i 1 k} y_{i 1 k t}+\lambda_{i 2} \sum_{k=1}^{n_{i}} \gamma_{i 2 k} y_{i 2 k t}$ for each type of transport.

Weight coefficients $\alpha_{i}$ and integral estimate $\mathrm{W}_{\mathrm{t}}$ of the transport system are determined similarly.

$3^{\text {rd }}$ stage. Analysis of Ukraine transport system integral estimation dynamics and certain modes of transport in $2004-2016$ and their graphical interpretation (Table 2).

Table 2: Ukraine Transport System Integral Estimates

\begin{tabular}{|c|c|c|c|c|c|c|c|c|}
\hline $\mathrm{Y}$ & 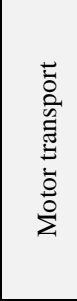 & 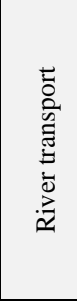 & 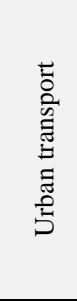 & 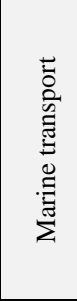 & 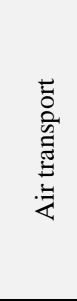 & 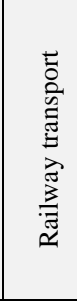 & 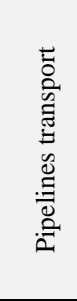 & 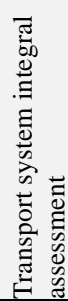 \\
\hline 2004 & 0 & & 1 & 70 & 17 & 115 & 00 & 0,837 \\
\hline 2005 & & & 0,9 & & & & & \\
\hline 2006 & 0,672 & 0,977 & 0,945 & 0,925 & 0,774 & 0,967 & 0,851 & 0,873 \\
\hline 2007 & 731 & 0,965 & 10 & 0,860 & & 0, & & 75 \\
\hline 2008 & 0,816 & 0,824 & 0,889 & 0,814 & \begin{tabular}{|l|}
0,728 \\
\end{tabular} & 0,950 & 0,825 & 0,835 \\
\hline 2009 & 733 & 0,615 & 0,776 & 0,711 & 0,632 & 0,871 & 0,716 & 0,722 \\
\hline 2010 & 0,806 & & & 0,722 & 0,676 & 0,885 & 0,590 & 0,710 \\
\hline 2011 & 0,895 & 0,452 & 0,767 & 0,713 & \begin{tabular}{|l}
0,737 \\
\end{tabular} & 0,884 & 0,530 & 0,711 \\
\hline 2012 & 0,909 & 85 & 0,758 & 0,677 & \begin{tabular}{|l|}
0,734 \\
\end{tabular} & 0,875 & \begin{tabular}{|l|}
0,408 \\
\end{tabular} & 0,678 \\
\hline 2013 & 0,852 & & 0,738 & 0,684 & 0,657 & 0,828 & 0,412 & 0,624 \\
\hline 2014 & 0,802 & 0,322 & & 0,190 & \begin{tabular}{|l|}
0,525 \\
\end{tabular} & 0,719 & \begin{tabular}{|l|}
0,350 \\
\end{tabular} & 0,512 \\
\hline 2015 & 0,740 & 0,339 & 0,628 & 0,190 & 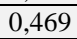 & 0,691 & 0,348 & 0,487 \\
\hline 2016 & 9,901 & 0,354 & 0,612 & 0,180 & 0,578 & 0,656 & 0,354 & 0,519 \\
\hline
\end{tabular}

Source: calculated by the authors on the basis of statistical data of the State

Statistics Service of Ukraine [21-22]

Dynamics of land transport integrated assessment is shown in Figure 1, air and water - in Figure 2, pipeline - in Figure 3, the entire transport systemin ure 4.

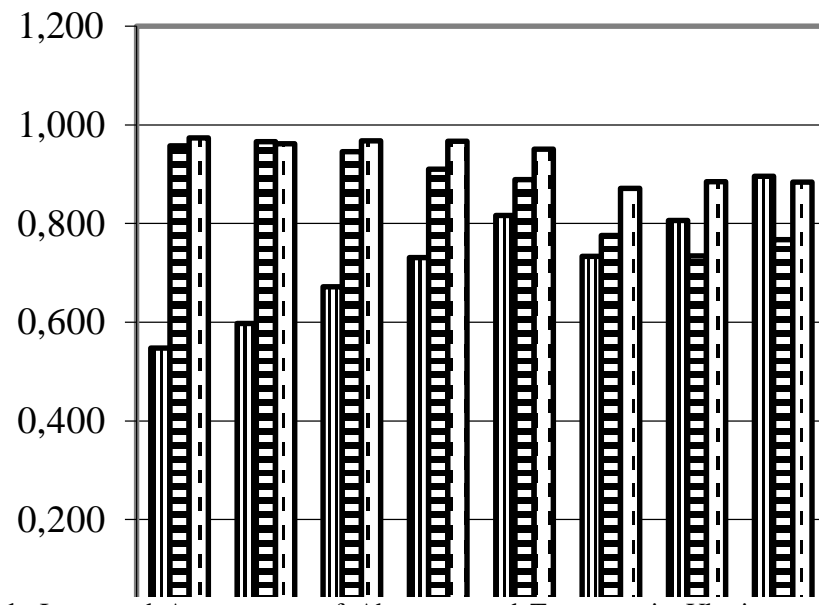

Fig. 1: Integrated Assessments of Above-ground Transport in Ukraine, $2004-2016$

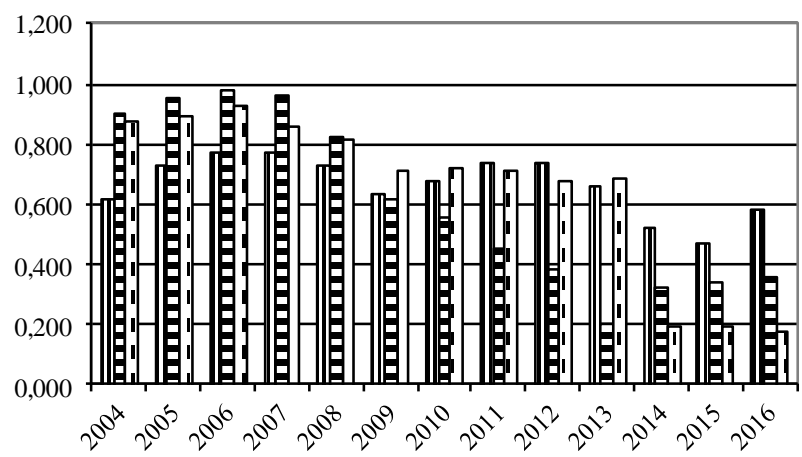

0 Air ERiver $\square$ Sea

Fig. 2: Integral Assessments of Air and Water Transport in Ukraine, 2004 $-2016$

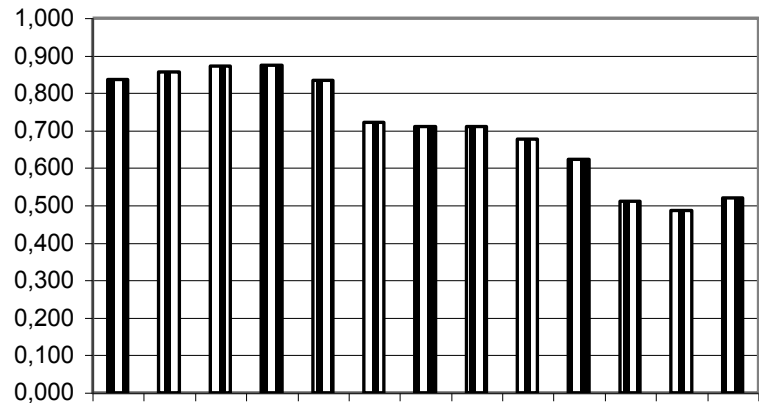

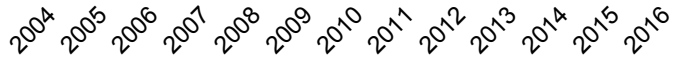

Fig. 3: Integral Assessments of Pipeline Transport in Ukraine, 2004 2016

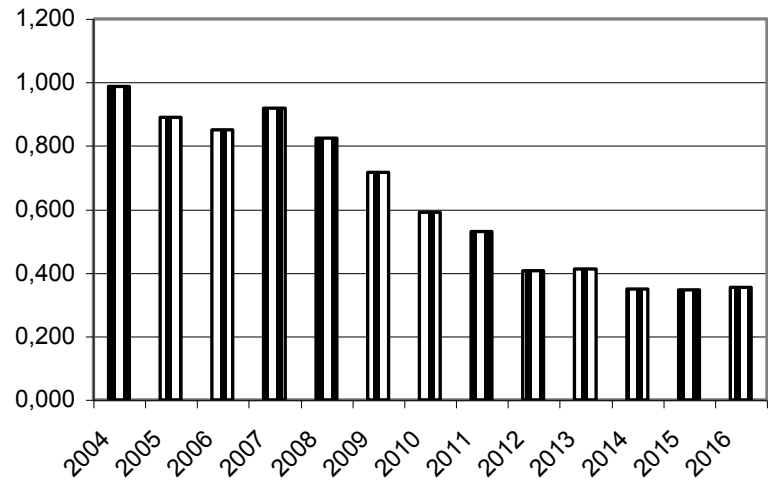

Fig. 4: Integral Assessments of the Transport System in Ukraine, 2004 2016

The results of transport system estimation in Ukraine make it possible to conclude that the level of its development is insufficient. Among the reasons of this situation are transport and logistics technologies and objects of multimodal transportation low level of development, disproportion in the development of certain modes of transport and technical backwardness.

Stage 4. Determining peculiarities of forming Ukraine's transport system development potential in terms of global challenges.

Analysis of various methodological approaches to studying the country's transport potential and determining the nature of its changes should take into account the following [1-5, 24-26]: change in the interests of transport system entities, which affects change in its subsystems integral indicators (Fig. 1); correspond- 
ence of revealed changes (and thus efficiency of the system and its subsystems functioning) to the existing state strategies of their development in the specific economic conditions; change in the content of state policy, since during the investigated period there was a large-scale privatization of individual components of the state transport system and, accordingly, mechanisms for managing their development.

Obtained results show that integrated estimation of the transport system in Ukraine was increasing in $2004-2007$, and then period of downturn followed that lasted until 2015. The biggest decline of this integral indicator occurred in 2009 (by 14\%) and in 2014 (by 16\%). In 2016 this indicator increased slightly (by $7 \%$ compared to the previous year), but this year's estimate is only $60 \%$ of the maximum estimate for the investigated period.

Integral estimate of motor transport also increased in 2016 by $22 \%$ compared to the previous year and amounted to $99 \%$ of the maximum value achieved in 2012. During investigated period, the biggest decrease of this estimate took place in 2009 (by 10\%), but the recession lasted for only a year. Estimation of motor transport was decreasing by 6-8\% annually from 2013 to 2015, in other years dynamics of this estimation was positive.

Integrated estimation of river transport was growing from 2004 to 2006. Then recession began that lasted until 2014. The decline was particularly significant in 2009 (by $25 \%$ compared to the previous year) and in 2013 (by $48 \%$ relatively to 2012). In 2014, this estimate increased by $62 \%$ compared to the previous year, but the level of 2012 has not been achieved. In 2015-2016 there was a slight increase of the indicator (by $4-5 \%$ annually). As a result, the estimate of river transport in 2016 was equal to $36 \%$ of its maximum value during the study period.

Integral estimation of urban transport during the study period increased only in 2005 (by 1\%) and in 2011 by 5\%. In other years, the indicator tends to decrease. In average, the city transport rate point was decreasing by $4 \%$ annually, due to which it was $63 \%$ of the maximum in 2016.

The integrated estimation of marine transport was slightly increasing until 2006, and then there was a decline of this indicator until 2009. In 2009-2013, the indicator was relatively stable, and in 2014 it decreased by $72 \%$ and remained at the same level in 2015. In 2016 , the indicator decreased by $5 \%$ and was equal to $19 \%$ of the maximum value during the study period.

The integrated estimation of air transport increased by $23 \%$ in 2016 compared to the previous year, and amounted to $75 \%$ of the maximum value achieved in 2006. During the investigated period, the largest decrease of this estimate was in 2009 (by 13\%) and in 2014 (by 20\%). The rating of air transport was decreasing in 20082009 and in 2013-2015, in other years the dynamics of this estimation was positive.

Integral estimation of railway transport was practically unchanged in 2004-2008, in 2009 there was a slight decrease (by 8\%), after which the estimate stabilized until 2012. From 2013, the value of this indicator decreased and in 2016 it reached $95 \%$ of the level of the previous year and $67 \%$ of the maximum value for the period under study.

The value of the integrated estimation of pipeline transport condition was in average decreasing by $15 \%$ annually in 2007-2012; in 2016 this indicator was equal to $102 \%$ of the previous year level, but $36 \%$ of the maximum value.

Thus, conducted calculations testify about significant changes in the traffic flow potential and changes in its role in the economic development of Ukraine as a result of reorientation of passenger and cargo flows, geographical change of key partners in the field of foreign economic activity, as well as processes of changing vector of the national economy development and realization the tasks of the country's European integration. Besides, impact of political factor (RF aggression and loss of the corresponding territories and the Crimea) has in fact led to the loss of the country's transport potential.
Stage 5. Assessment of transport system development management effectiveness in Ukraine.

Undoubtedly, integral estimates of transport system development as a whole and its subsystems in particular, depend on their development existing potential (including available resources) and effectiveness of the current management system (existing instruments and mechanisms for traffic controlling, effectiveness of the created institutes of management).

Defined integrated assessments can be used to evaluate the efficiency of transport modes management at the country level. Estimation of $\mathrm{i}$-th type of transport management efficiency in $\mathrm{t}$-th is determined by equality

$W_{t}=\sum_{i=1}^{N} \alpha_{i}\left(\lambda_{i 1} \sum_{k=1}^{m_{i}} \gamma_{i 1 k} y_{i 1 k t}+\lambda_{i 2} \sum_{k=1}^{n_{i}} \gamma_{i 2 k} y_{i 2 k t}\right)$

that is equal to integral assessment ratio of this mode of transport operation to an integrated assessment of its resource potential. Calculated integral estimates are shown in Figure 5.

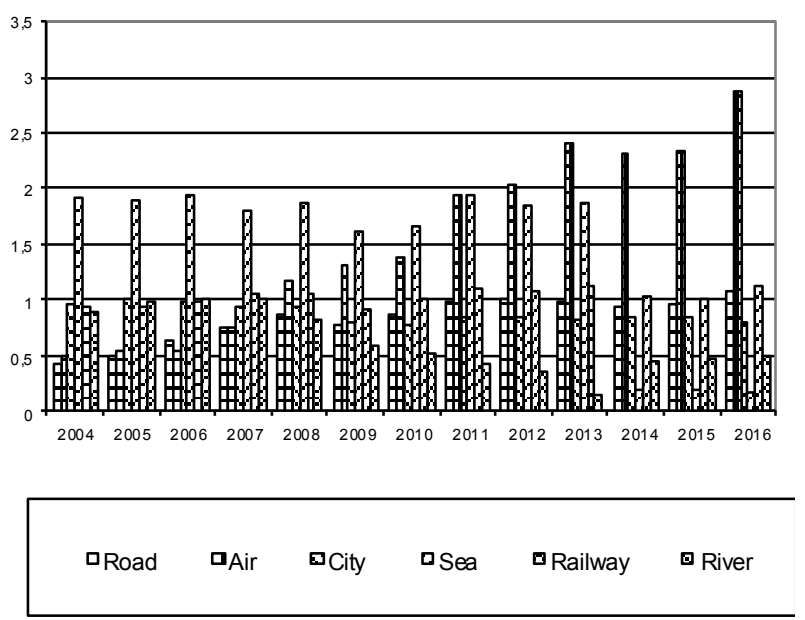

Fig. 5: Integral Assessments of Transport System of Ukraine Management Efficiency Development

Thus, the study carried out extends the idea about peculiarities of formation and use of resource potential, as well as functioning of the country's transport system and its subsystems, which enables conducting analysis, control, accounting, planning, forecasting and regulation of the industry as a whole. To solve these problems it is necessary to ensure increase in efficiency of a unified transport system management, which requires improvement of informational and analytical support of this branch. An important part of this is proposed methodological approach to objective assessment of transport system management effectiveness, considering impact of external and internal factors combination.

In terms of national transport strategy of Ukraine project for the period up to 2030, priority directions include increased competitiveness and efficiency of transport system, innovative development of transport sector and re-implementation of global investment projects [23]. Implementation of these tasks suggests using the latest information technologies: integrated information systems for passengers and cargo owners, systems for informing about the services provided, introduction of electronic and integrated automatic fare collection system, a unified information system of technological interaction of different modes of transport, "cloud" technologies for data storage and intelligent transport systems. Necessary measures for certain modes of transport development include modernization of the state management railways system and introduction of flexible tariff policy, creation of corresponding international requirements of transport corridors, improvement of motor roads quality and new first and second categories roads construction, strengthening material and technical base of domestic air 
carriers and creation of new terminals at airports, development of river and sea ports infrastructure.

The developed methodology of transport system integrated assessment and its management effectiveness enables evaluating effectiveness of implementation of these and other projects by comparing the corresponding integral estimates.

\section{Conclusion}

Developed methodological approach to integrated assessment of the country's transport system development and its management effectiveness is based on the use of official statistical indicators and reflects correlation between them. Results obtained from realization the proposed approach can be used while choosing strategic priorities of the state transport policy and evaluating effectiveness of this policy; strategic planning of transport infrastructure development and substantiation the ways of its optimization under changing the role of both modes of transport, and their economical, social, environmental performance in the system of internal and external challenges.

Universality of the proposed methodological approach consists in the fact that integrated estimates of Ukrainian transport system and its subsystems corresponding to different modes of transport can be used by the Department of Communication and Analytical Work, as well as by the Department for Strategic Development of Infrastructure and Investments of the Ministry of Infrastructure of Ukraine, for the purpose of analyzing, controlling, accounting, planning, forecasting and regulating the activity of this industry, determining investment attractiveness of its industries and in implementation of transport system investment and innovation development projects.

Thus, the proposed approach is the basis for determining vector of market transformations in transport infrastructure, taking into account socially optimal level of its development, as well as considering innovative and investment projects financing that ensure further integration of the single transport network in Ukraine into the common-European network, main world goods and passenger traffic taking into account geographical location, investment attractiveness of transport infrastructure for internal and external partners.

\section{References}

[1] Shui C, Donga Y \& Maimaitiminga M (2014), Study on the Evaluation Framework System for Regional Comprehensive Transport Planning. Procedia - Social and Behavioral Sciences, 138, $492-$ 500 .

[2] Czech A \& Lewczuk J (2017), Statistical Assessment of the Development of the Transportation System in Chosen Countries - an International Approach. Procedia Engineering, 182, 112 - 119.

[3] Jiang, C. (2009, May). A Model of Evaluating Transportation System Efficiency Based on Data Envelopment Analysis Approach. Paper presented at the Electronic Commerce and Security 2009, Nanchang. DOI: 10.1109/ISECS.2009.87

[4] Nazarova L.V., Skupskyi R.M. \& Gryshova I.Yu. (2016), Osoblyvosti dii organizaciino-ekonomichnogo mekhanizmu funktsionuvannia regionalnykh transportno-logistychnykh system. Ukrainskyi zhurnal prykladnoi ekonomiky, 1(2), 86-95.

[5] Iksarova N.O. (2010), Transportna infrastruktura yak komponent ekonomichnoi bezpeky Ukrainy. Ekonomichnyi prostir, 36, 55-61.

[6] Zakharova O,V, (2011), Globalni chynnyky rozvytku potentsialu svitovoi transportnoi systemy. Ekonomichnyi chasopys-XXI, 9-10, 14-17.

[7] Preiger D.K., Sobkevych O.V. \& Yemelianova O.Yu. (2012), Strategichni napriamy rozvytku transportnoi galuzi Ukraiini $u$ pisliakryzovii period: analit. dop.. K: NISD.

[8] Basbas S. \& Papanikolaou A. (2009), Evaluation of a sustainable urban transport system through the use of the transecon methodology. International Journal of Sustainable Development and Planning 4(1), 18-34. DOI: 10.2495/SDP-V4-N1-18-34

[9] Li J., Chen X., Li X. \& Guo X. (November 2013), Evaluation of Public Transportation Operation based on Data Envelopment Anal- ysis. Procedia - Social and Behavioral Sciences 96(6), 148-155. DOI: $10.1016 /$ j.sbspro.2013.08.020

[10] Yaremchuk R.Ye. (2013), Metodychni pidkhody do vyznachennia ta otsinky transportno-logistychnoi funktsii metropoliinogo mista. Sotsialno-ekonomichni problemy suchasnogo periodu Ukrainy, 2(100), 86-96

[11] Yang Y., Zhang P. \& Ni S. (2014), Assessment of the Impacts of Urban Rail Transit on Metropolitan Regions Using System Dynamics Model. Transportation Research Procedia, 4, 521-534. DOI: 10.1016/j.trpro.2014.11.040

[12] Zablodska I.V., Buzko I.R., Zelenko O.O. \& Khoroshilova I.O. (2016). Infrastrukturne zabezpechennia rozvytku transportnoi systemy regionu: kolektyvna monografia. Sievierodonetsk: Publishing House of Volodimir Dahl East Ukrainian National university.

[13] Andriushchenko K.A. (2012), Teoretychni aspekty rozvytku dorozhno-transportnoi systemy yak skladovoi vyrobnychoi infrastruktury regionu. Derzhavne upravlinnia: udoskonalennia ta rozvytok. .Retrieved from http://www.dy.nayka.com.ua/?op=1\&z=379

[14] Ahromkin E.M. \& Alekseev A.S. (2015), Rationalize of transport development system in the region. Ekonomika i pravo, 3(41), 12 18 .

[15] Janic M. (2016). Transport Systems: Modelling, Planning, and Evaluation. CRC Press

[16] Shevchenko A.I. (2017), Stalyi rozvytok zaliznychnogo transportu Ukrainy z pozytsii ekonomichnoi bezpeky. Visnyk ekonomichnoi nauky Ukrainy, 1(32), 116-124.

[17] Dedík M., Gašparík J. \& Záhumenská Z. (2017). Quality Assessment in the Logistics of Rail Passenger Transport. Paper presented at MATEC Web of Conferences 134, 00009 DOI: 10.1051/matecconf/201713400009 LOGI 2017

[18] Schmale J., von Schneidemesser E. \& Dörrie A. (2015), An Integrated Assessment Method for Sustainable Transport System Planning in a Middle Sized German City. Sustainability 7, 1329-1354. DOI:10.3390/su7021329.

[19] Zakon Ukraiiny. Pro transport. (Vidomosti Verkhovnoi Rady Ukraiiny (VVR), 51, 446.

[20] Medykovskii M.O, \& Shunevych O.B. (2011), Doslidzhennia efektyvnosti metodiv vyznachennia vagovykh koefitsiyientiv vazhlyvosti. Visnyk Khmelnytskogo natsionalnogo universytetu, 5, 176-182.

[21] Transport i zviaazok Ukrainy za 2010 rik. - K. : Derzhavna sluzhba staty`sty`ky`Ukrayiny`2011.

[22] Transport i zviaazok Ukrainy za 2016 rik. - K. : Derzhavna sluzhba staty`sty`ky`Ukrayiny`2017.

[23] Ministry of Infrastructure of Ukraine. Official site. Retrieved from http://www.mtu.gov.ua/

[24] Alkema V.H. (2012). Henezys struktury transportnoho potentsialu Ukrainy v umovakh staloho rozvytku. Marketynh i menedzhment innovatsii, № 2, s. $172-180$.

[25] Komelina O.V. Stratehiia transformatsii innovatsiinoinvestytsiinoho prostoru Ukrainy: teoriia, metodolohiia i praktyka: monohrafiia /O.V. Komelina - K.: TOV «DKS tsentr», 2010. $486 \mathrm{~s}$.

[26] Komelina O.V. Informatsiino-metodychne zabezpechennia upravlinnia rozvytkom ahrarnoho sektoru ekonomiky rehioniv / O.V. Komelina, N.L. Panasenko // Ekonomichnyi chasopys-XXI. Kyiv, 2013. - № 11-12(1). - S. 38 - 42. 